\title{
An exploratory study of the South African concentrated solar power sector using the technological innovation systems framework
}

\author{
S. Potts ${ }^{1}$, D.R. Walwyn²* \\ 1 Gordon Institute of Business Science, University of Pretoria, 26 Melville Road, Illovo, Johannesburg, \\ South Africa; https://orcid.org/0000-0003-3824-2139 \\ 2 Department of Engineering and Technology Management, University of Pretoria, Private Bag X20, Hatfield, \\ Pretoria 0028, South Africa; https://orcid.org/0000-0002-0545-0604
}

\begin{abstract}
Wide-scale deployment of variable renewable energy (wind and solar photovoltaic) is constrained by its associated requirements for energy storage, the technologies for which are currently too expensive to be routinely used. Concentrated solar power (CSP), with its inherent storage capacity, offers semi-dispatchable electricity at large scale. However, its deployment to date has been restricted by high capital costs and the limited geographical locations with optimal solar radiation to attain required efficiencies. South Africa, with its abundant solar resources, has the potential to develop an export-competitive CSP industry by leveraging existing capabilities in innovation, manufacturing and construction, but has yet to attain this goal. This study applied a qualitative, exploratory approach and the framework of technological innovation systems (TIS) to understand the factors that are currently prohibiting the country from being a global leader in CSP. The assessment has revealed the presence of largely immature TIS, characterised by a heavy reliance on imported technology and market support from the state-supported procurement programme. The advancement of CSP remains contingent on further allocation of CSP procurement targets in this programme and sufficient support to develop entrepreneurial activity. An integrated industrial policy strategy, which can ensure technology transfer and address the high cost of CSP, is recommended as a means of addressing the barriers to its development as a competitive industry.

Keywords: renewable energy, industrial policy, entrepreneurial activity

Highlights

- The sector is highly reliant on the demand-side incentive of the power producers procurement programme.

- Industrial policies to stimulate entrepreneurial activity and sector legitimacy are essential for longterm sustainability.

- The levelised cost of energy from concentrated solar power must be further reduced if it is to compete against other technologies.
\end{abstract}

Journal of Energy in Southern Africa 31(2): 1-18

DOI: http://dx.doi.org/10.17159/2413-3051/2020/v31i2a7725

This work is licensed under a Creative Commons Attribution-ShareAlike 4.0 International Licence Published by the Energy Research Centre, University of Cape Town ISSN: 2413-3051 https://journals.assaf.org.za/jesa

Sponsored by the Department of Science and Technology

* Corresponding author: Tel: +27 (0)824161534:

email: david.walwyn@up.ac.za 


\section{Introduction}

Concentrated solar power (CSP) could be an important contributor to the decarbonisation of global energy systems, given its minimal carbon emissions per unit of energy generated (Nelson et al., 2014). However, studies have shown that is a non-viable technology at its present level of performance and cost (Salisu et al., 2019; Mahlangu et al., 2018; Craig et al., 2017) and its future prospects appear to be limited to specific locations characterised by high levels of solar radiation, cheap land, and low cost of capital (Soomro et al., 2019). It remains, however, an active area of research, driven partly by its inherent advantage over the non-dispatchable renewable energy technologies of allowing a degree of energy storage. In this sense, CSP can be considered as a niche technology that has been implanted at small scale as a transition experiment, but is yet to establish itself at the meso or system level (Geels et al., 2006; Kemp et al., 1998).

South Africa has been a significant actor in such experiments, with the incorporation of CSP within its renewable energy programme. In 2018, the country ranked third in new CSP capacity additions and by mid-2019 its total CSP capacity had reached $500 \mathrm{MW}$, which is about $10 \%$ of global capacity (REN21, 2019). Moreover, its abundant solar resources and significant manufacturing expertise make the country an ideal location to develop an internationally competitive CSP manufacturing sector (Bischof-Niemz, 2019). Unfortunately, the goal for the sector of being export-oriented and internationally competitive has not been realised; it remains inwardly focussed, with a heavy dependence on imported technology.

This study sought to understand the reasons for the failure of the South African CSP sector to be a global player, and specifically the factors responsible for its inability to break through from the micro to the meso level. In the initial phase, the level of the sector's maturity, based on an analysis of the seven functions of the technological innovation systems (TIS) framework (Hekkert et al., 2007), was assessed. The results were then used to identify the interventions that may be required to deepen its development as an internationally competitive CSP sector. The framework of TIS has not previously been applied to CSP and is particularly useful in this context since it provides a comprehensive approach to assessing the system constraints to the overall process of technological change.

\section{Background \\ 2.1 Concentrated solar power capacity: Global and South Africa}

Planned CSP projects are tracked by the International Energy Agency through the SolarPACES programme, which aims to promote collaborative development, testing and marketing of CSP plants (SolarPACES, 2019). Project developers supply information that is reviewed by the SolarPACES experts. Projects are then indexed according to a number of parameters, including the type of technology and the operational phase of the project. There are four main forms of CSP technologies, namely parabolic trough collectors (PTCs), solar tower technology (STT), linear Fresnel collectors (LFCs), and parabolic dish reflectors, with the installed ratios of total capacity being about $82 \%, 13 \%, 4 \%$ and $1 \%$ respectively (Islam et al., 2018; Zhang et al., 2013). The SolarPACES database shows that the majority of operational CSP projects utilise PTC technology (Figure 1). It is, however, anticipated that the focus will

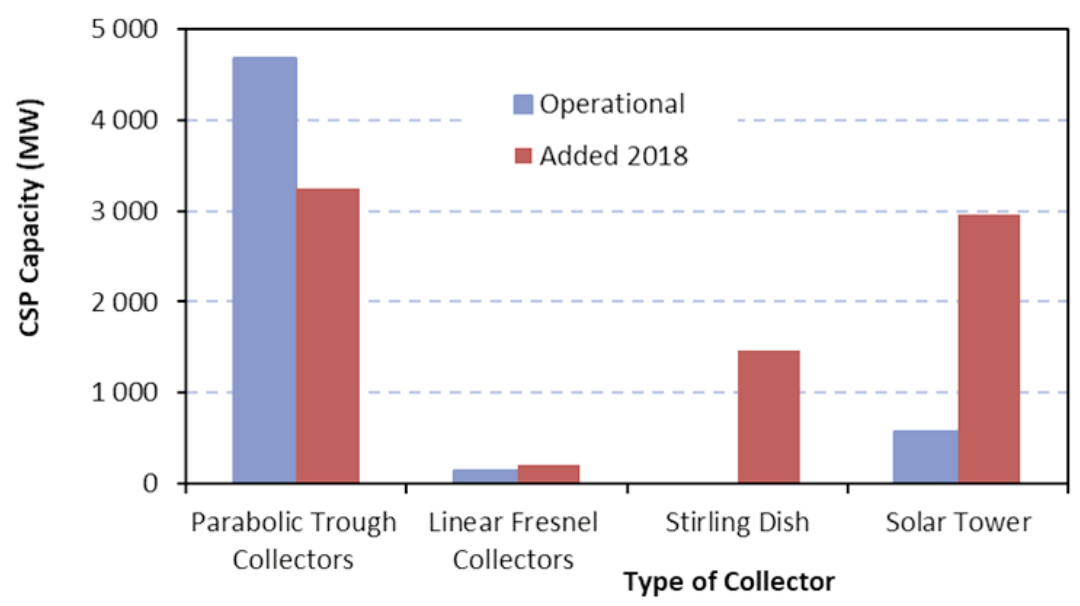

Figure 1. Installed capacity for the four concentrated solar power technologies (SolarPACES, 2019). 


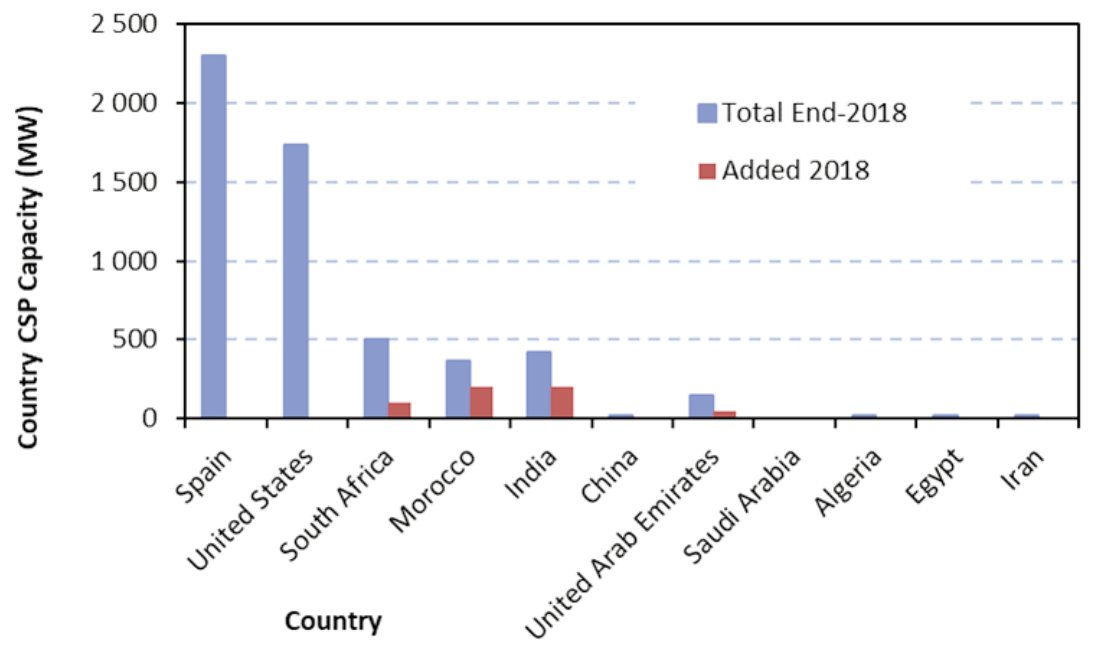

Figure 2. Global installed concentrated solar power capacity by end 2018 (REN21, 2019).

shift towards the more efficient STT as more projects come on line (Behar et al., 2013).

As of 2017, the global installed capacity of CSP was $4951 \mathrm{MW}$, an increase of more than 4.4 GW since 2008 (Figure 2). Despite these significant strides in CSP installation over the years, when compared to PV with a global installed capacity of about $385 \mathrm{GW}, \mathrm{CSP}$ is considered a niche market (Lilliestam et al., 2018). Spain accounts for more than half of the installed capacity (2 $300 \mathrm{MW}$ ), followed by the USA (1 758 MW) and South Africa (500 MW), which explains the major role that Spanish companies played in the development of CSP facilities, both within Spain and abroad. The Spanish dominance of installed CSP capacity was attributed largely to the use of a renewable energy feed-in tariff (REFIT) policy instrument to stimulate CSP development. The REFIT is an incentive whereby governments pay private electricity producers for renewable energy electricity at a predetermined price (NERSA, 2009). Between 2004 and 2007, the Spanish government introduced two separate remuneration models, which together created favourable economic conditions for CSP development and construction. The REFIT tariffs were initially very generous (300\% of the reference tariff), but were adjusted downwards from 2007 to 2012 and then stopped in 2013 for all new applicants. This was replaced by a mechanism referred to as a 'complementary payment', which added a premium of $7.5 \%$ to the purchase price of electricity (SolarPACES, 2019).

Spain's success as a CSP manufacturer is evident in the summary of South Africa's installed CSP capacity, as shown in Table 1. All the engineering, procurement and construction (EPC) was undertaken by Spanish companies, all of the technology was sourced from Spain, and only two of the six developers have South African partners. South Africa's CSP capacity was driven by the country's renewable energy programme, which was implemented in 2011 as a means of stimulating the adoption of renewable energy technologies and diversifying its energy sector from an almost exclusive dependence on coal (Mahlangu and Thopil, 2018;

Table 1: Main developers and engineering, procurement and construction firms for the South African concentrated solar power projects (Energyblog, 2019; REN21, 2019; Relancio et al., 2016).

\begin{tabular}{|c|c|c|c|c|c|}
\hline Project name & $\begin{array}{l}\text { Main developer(s) } \\
\text { (country of origin) }\end{array}$ & $\begin{array}{l}\text { Engineering, procurement } \\
\text { and construction } \\
\text { (country of origin) }\end{array}$ & Location & Status & $\begin{array}{l}\text { Capacity } \\
\text { (MW) }\end{array}$ \\
\hline Bokpoort & $\begin{array}{c}\text { Karoshoek Consortium } \\
\text { (Saudi Arabia) }\end{array}$ & $\begin{array}{l}\text { Acciona (Spain) } \\
\text { SENER (Spain) }\end{array}$ & Groblershoop & Fully operational & 50 \\
\hline Ilanga & $\begin{array}{c}\text { ACS Cobra (Spain) } \\
\text { Emvelo (South Africa) }\end{array}$ & ACS Cobra (Spain) & Kimberley & Fully operational & 100 \\
\hline $\begin{array}{l}\text { Kathu Solar } \\
\text { Park }\end{array}$ & $\begin{array}{c}\text { Engie (France) } \\
\text { Public Investment } \\
\text { Corporation (South Africa) }\end{array}$ & $\begin{array}{l}\text { Acciona (Spain) } \\
\text { SENER (Spain) }\end{array}$ & Kuruman & Partially operational & 100 \\
\hline KaXu Solar 1 & Abengoa (Spain) & Abeinsa (Spain) & Pofadder & Fully operational & 100 \\
\hline Khi Solar 1 & Abengoa (Spain) & Abeinsa (Spain) & Upington & Fully operational & 50 \\
\hline Xina & Abengoa (Spain) & Abeinsa (Spain) & Pofadder & Fully operational & 100 \\
\hline
\end{tabular}


Walwyn et al., 2014). Referred to as the Renewable Energy Independent Power Producers Procurement Programme (REI4P), the initiative led to the installation of $6.4 \mathrm{GW}$ of renewable energy capacity.

Spain's success in South Africa's CSP procurement can be explained by the support from the Spanish government for the CSP sector, but it belies the geographic advantage that South African companies could utilise in their own strategies. South Africa receives an annual average direct normal irradiation (DNI) of 2816 $\mathrm{kWh} / \mathrm{m} 2 /$ year in the Northern Cape region, which makes it an ideal location for CSP. This is higher than the average for both Spain (2 100 $\mathrm{kWh} / \mathrm{m} 2 /$ year $)$ and the USA (2 700 $\mathrm{kWh} / \mathrm{m} 2$ /year) (Knorr et al., 2016), yet it lags behind these countries in terms of installed capacity.

\subsection{Overview of concentrated solar power}

The CSP technology uses mirrors or lenses (collectively termed 'solar collectors') to concentrate sunlight onto a small receiver area containing a heat transfer fluid (HTF). The objective is to heat the fluid to produce steam, which drives a turbine to generate electricity; the technology on the back end of the plant is essentially the same as a conventional fossil fuel plant. The HTF also functions as thermal storage, whereby the fluid can be stored for a period and subsequently mobilised to heat water when electricity is needed. The first CSP plant was installed in California, USA in the mid-1980s, and is considered to embody 'young' technology compared with other energy technologies (Fuqiang et al., 2017). The technology is still progressing down its learning curve and there is still significant potential for large cost reduction in technology development (Lilliestam and Pitz-Paal, 2018). As described above, the four main forms of CSP technologies are PTCs, STT, LFCs and parabolic dish reflectors, with the installed ratios of total capacity of respectively about $82 \%, 13 \%$, $4 \%$ and 1\% (Islam et al., 2018; Zhang et al., 2013). The technologies are classified according to the way the solar collectors concentrate the sun's rays. The PTC and LFC are classified as line-focusing systems as they concentrate the rays along a focal line, whereas the parabolic dish reflector and STT are point-focusing systems, as they concentrate the rays towards a single focal point (Reddy et al., 2013). The dominant design at present is STT, where the receiver is in a high tower at the centre of a field of mirrors laid out in concentric circles. The mirrors, referred to as 'heliostats', are individually controlled by a computer and track the sun along two axes to constantly focus the maxi- mum amount of direct solar irradiation onto the receiver. The HTF, typically a molten salt, is pumped up to the receiver, heated to temperatures in excess of $600{ }^{\circ} \mathrm{C}$ and then returned to the storage area, where it is used to produce steam immediately or stored for later use (Behar et al., 2013). Tower technology can achieve higher temperatures and therefore higher efficiencies than PTC and LFC, and it is therefore anticipated that it will remain the dominant technology (Fuqiang et al., 2017). Concentrating solar power is still a minor and expensive technology (IRENA, 2019). Its ability to store heat and flexibly dispatch electricity, even when there is no solar radiation, nonetheless renders CSP a semi-dispatchable form of renewable energy and provides it with a competitive advantage over PV and wind (Zhang et al, 2013). Currently, CSP can be used as a source of peak power - i.e., power needed when the demand is highest, typically in the early evenings - and plants that provide this form of service are called 'peaking plants'. It is envisaged that, with further technological advancement, CSP could provide base-load electricity, i.e., the power required to supply continuous demand. As a result, CSP was described as a renewable energy technology that has significant potential to meet future energy demand (Teske et al., 2016). Despite the advantage of storage, CSP is not without its disadvantages. In order to reach the efficiencies that make CSP economical, high levels of solar irradiance are required. Using the metric of DNI, it has been estimated that CSP systems are only economic in regions with a minimum DNI of 1800-2 000 $\mathrm{kWh} / \mathrm{m} 2 /$ year, thereby restricting their use (Behar et al., 2013; Trieb et al., 2009). Additionally, CSP requires large quantities of water for cooling steam, cleaning mirrors, and other process requirements (about 3500 litres/ MWh, compared with less than 5 litres/MWh in $\mathrm{PV}$ or wind energy). This is a severe drawback for CSP plants attempting to operate in waterstressed regions and raises environmental impact concerns (Macknick et al., 2012). Finally, the levelised cost of energy (LCOE) for CSP is still significantly higher than for PV and wind renewable energy, and consequently the global share of CSP is much lower than these two more conventional renewable energy sources. This is discussed in more detail in Section 4.2.

\subsection{Analytical framework of technological innovation systems}

It is apparent from the previous section that CSP can be considered as a niche technology with the potential, far from realised, to decarbonise energy systems. In this sense, its further 
development, and particularly the likelihood that it will become a widely-adopted solution to the carbon emissions crisis, can be suitably analysed using the framework of TIS. This approach, which is based broadly on theories of socio-technical transitions, encompasses all the elements required to institutionalise a new technology and is a comprehensive method for identifying the barriers and weaknesses in an immature transition such as the adoption of CSP (Nelson et al., 2018; Hekkert et al., 2011; Bergek et al., 2008a; Hekkert et al., 2007). In the last two decades the socio-technical TIS framework gained prominence in literature, as a valuable conceptual building block of sustainability transitions research (Hekkert et al., 2011; Truffer, 2015). The framework concentrates on identifying the conditions required to develop and diffuse emerging technologies. As such, it is highly relevant for studying renewable energy technology (RET) diffusion, which is known to be an essential component in the sustainability transition towards a decarbonised energy sector (United Nations, 2015). To manage, facilitate and steer this transformation process requires an in-depth understanding of the factors that contribute to the generation and diffusion of these technological innovations, as well as the dynamics between them; i.e., it requires a systems approach (Markard et al., 2008b). As stated by Jacobsson et al. (2000: 629): 'It is the character of this system that we need to comprehend if we are to understand how an energy system is transformed'. The TIS framework is part of the innovation systems theoretical school. There are a number of such approaches, defined at different levels: the National Innovation System (Lundvall, 2010; Godin, 2009), Sectorial Innovation Systems (Malerba, 2002), Regional Innovation Systems (Kaihua et al., 2014; Chung, 2002), and TIS (Hekkert et al., 2007). Innovation systems theory claims that innovation and technology change occur through actors interacting with the system in which the technology is embedded (Hekkert et al., 2007). The performance of an innovation system depends on the interaction, as well as the flow and utilisation of knowledge, between the components and not their individual successes (Godin, 2009), i.e., it considers the 'business ecosystem' (Planko et al., 2017). The TIS can be conceptualised as a social network, comprising actors (organisations that contribute to a technology, e.g., knowledge institutes, industry, government) and institutions (these constitute 'the rules of the game' such as polices, technology standards and legislation that formally regulate, control and shape human interaction), centred around a specific technology (Markard et al., 2008a). It is noted that the innovation systems literature collectively refers to actors, institutions, networks and technology as the structural components of the TIS, which provide insight into who is active in the system (Suurs et al., 2009). It was more formally defined by Carlsson et al. (1991: 111) as 'a set of networks of actors and institutions that jointly interact in a specific technology field and contribute to the generation, diffusion and utilisation of variants of a new technology and/or new product'; and more recently as 'the set of actors and rules that influence the speed and direction of technological change in a specific technological area' (Hekkert et al., 2011: 3). One of the important advantages of the TIS framework is that it can be used to identify and map the diverse range of interlinked actors and activities that are required to transform an innovation from an idea to a marketable product or service (Planko et al., 2017). The TIS analysis is, therefore, often used to determine which of these actors and activities are developed to the point where they are advancing the technology and which are underdeveloped, requiring further policy intervention. This maturity mapping is undertaken through applying the TIS 'functions of innovation systems' approach (Hekkert et al., 2007), as shown diagrammatically in Figure 3. Step 1 involves categorising the activities or processes in the IS according to seven different functions, details of which are depicted in Figure 3 and Table 2. In Step 2, the level of maturity of that function is then determined by posing diagnostic questions to experts or key stakeholders; a function is deemed mature if the level of activity is sufficient to develop that particular technology. A functions level of maturity is then scored on a 5-point Likert scale (where $1=$ very weak and $5=$ very strong) and the results can be plotted to highlight areas for improvement. Once the level of maturity is established, Step 3 involves devising measures to enhance supporting factors and counteract those that block progress (Kebede et al., 2017; Markard and Truffer, 2008b; Hekkert et al., 2007). The results of Step 3 can then be used by policy makers to develop instruments which will enable a technology to realise its full potential within a specific environment (Bergek et al., 2015).

The functions used in Step 1 (and applied in this study) are based on the original set of functions as published by Hekkert et al. (2007) and shown in Table 2.

\subsection{Technological innovation systems and renewable energy technologies}

The TIS framework has been widely used to investigate the adoption or development of 
Table 2: Functions of a technological innovation system (Hekkert et al., 2007).

\begin{tabular}{|c|c|}
\hline Function & Description \\
\hline $\begin{array}{l}\text { F1: Entrepreneurial, } \\
\text { experimentation and } \\
\text { production }\end{array}$ & $\begin{array}{l}\text { Entrepreneurs convert inputs (new knowledge, networks and markets) into } \\
\text { outputs in the form of new business opportunities (Miremadi et al., 2018) and } \\
\text { are essential actors in a TIS; without their capacity to absorb and mitigate the } \\
\text { risk associated with testing new technologies and undertake commercial } \\
\text { experiments, the uncertainties associated with the development and diffusion } \\
\text { of a technology would not be resolved (Suurs and Hekkert, 2009). }\end{array}$ \\
\hline $\begin{array}{l}\text { F2: Knowledge } \\
\text { development }\end{array}$ & $\begin{array}{l}\text { This function refers to how technical and other forms of knowledge are } \\
\text { developed and combined in the innovation system (Bergek et al., 2008b). } \\
\text { Increase in knowledge development effort is signalled by an increase in } \\
\text { research and development activity (e.g. increasing number of academic } \\
\text { publications, PhD studies on the topic, emergence of research centres } \\
\text { investigating the technology, university and business collaborations), number of } \\
\text { patents filed and investments in R\&D. }\end{array}$ \\
\hline $\begin{array}{l}\text { F3: Knowledge } \\
\text { diffusion }\end{array}$ & $\begin{array}{l}\text { This function involves the exchange and diffusion of information between } \\
\text { actors within the network through knowledge-sharing interactions or through } \\
\text { the formation of partnerships, and reflects the extent of learning (Lundvall et } \\
\text { al., 2002). }\end{array}$ \\
\hline $\begin{array}{l}\text { F4: Guidance of the } \\
\text { search }\end{array}$ & $\begin{array}{l}\text { In a resource-constrained environment with multiple options available, choices } \\
\text { must be made as to which technologies to pursue and where to focus } \\
\text { activities. Focus is important, because without it, resources could become } \\
\text { diluted to the point where no options will flourish. In line with this, the } \\
\text { guidance of the search function refers to activities, incentives and mechanisms } \\
\text { that create visibility of needs and goals of technology users to aid in clearly } \\
\text { directing the allocation of resources along a specific path (Miremadi et al., } \\
\text { 2018; Hekkert et al., 2007). }\end{array}$ \\
\hline F5: Market formation & $\begin{array}{l}\text { This function covers to the extent to which new technologies have been able } \\
\text { to establish a market presence. It is often the case that specific interventions } \\
\text { are required to foster markets and demand for a new technology, which is } \\
\text { achieved by creating an artificial or niche market. In doing so, actors are able } \\
\text { to acquire knowledge about the technology (F2 and F3) and create } \\
\text { expectation (F4), thereby facilitating the growth of that technology (Suurs and } \\
\text { Hekkert, 2009). }\end{array}$ \\
\hline $\begin{array}{l}\text { F6: Resource } \\
\text { mobilisation }\end{array}$ & $\begin{array}{l}\text { This function refers to the allocation of financial and human capital as an } \\
\text { input towards knowledge development (F2) and capital investment more } \\
\text { broadly, including activities such as funds for long term R\&D projects, piloting } \\
\text { of technologies in niche markets (link to F1), and training personnel (Hekkert } \\
\text { et al., 2007). This function is important because without financial means and } \\
\text { the presence of actors with the requisite skills an emerging technology will not } \\
\text { be supported. }\end{array}$ \\
\hline $\begin{array}{l}\text { F7: Counteract } \\
\text { resistance to change/ } \\
\text { legitimation }\end{array}$ & $\begin{array}{l}\text { Legitimacy is a form of social acceptance and is required for resources to } \\
\text { be mobilised (Bergek et al., 2008b; Jacobsson, 2008). This function } \\
\text { therefore refers to activities related to the active advocacy of a new } \\
\text { technology that are required to counter resistance by members of an } \\
\text { incumbent regimewho may be opposed to the advancement of the new } \\
\text { technology (Suurs and Hekkert, 2009). Examples of advocacy activities } \\
\text { include political lobbying for resources and favourable tax regimes by } \\
\text { advocacy coalitions (collections of actors with a shared goal of shaping the } \\
\text { institutions towards favourable adoption of the technology). }\end{array}$ \\
\hline
\end{tabular}

RETs in different geographic regions, including photovoltaics (Kebede and Mitsufuji, 2017; Walwyn, 2016; Dewald et al., 2011), biopower (Wirth et al., 2011; Jacobsson, 2008), wind energy (Edsand, 2017; Reichardt et al., 2017; Bento et al., 2015), fuel cells (Musiolik et al., 2011; Markard and Truffer, 2008a) and tidal kite energy (Andersson et al., 2018). Despite differences in context and technology, several generic princi- ples can be extracted from these published TIS studies. For all countries, sufficient attention to F4 (guidance of the search) is critical (Wieczorek et al. 2013; Jacobsson et al. 2013). Indeed, recent studies argue that the two fundamental conditions for successful energy transitions are a high degree of (international) policy coordination (Wieczorek et al., 2013) and the development of a comprehensive policy mix (Reichardt et al., 

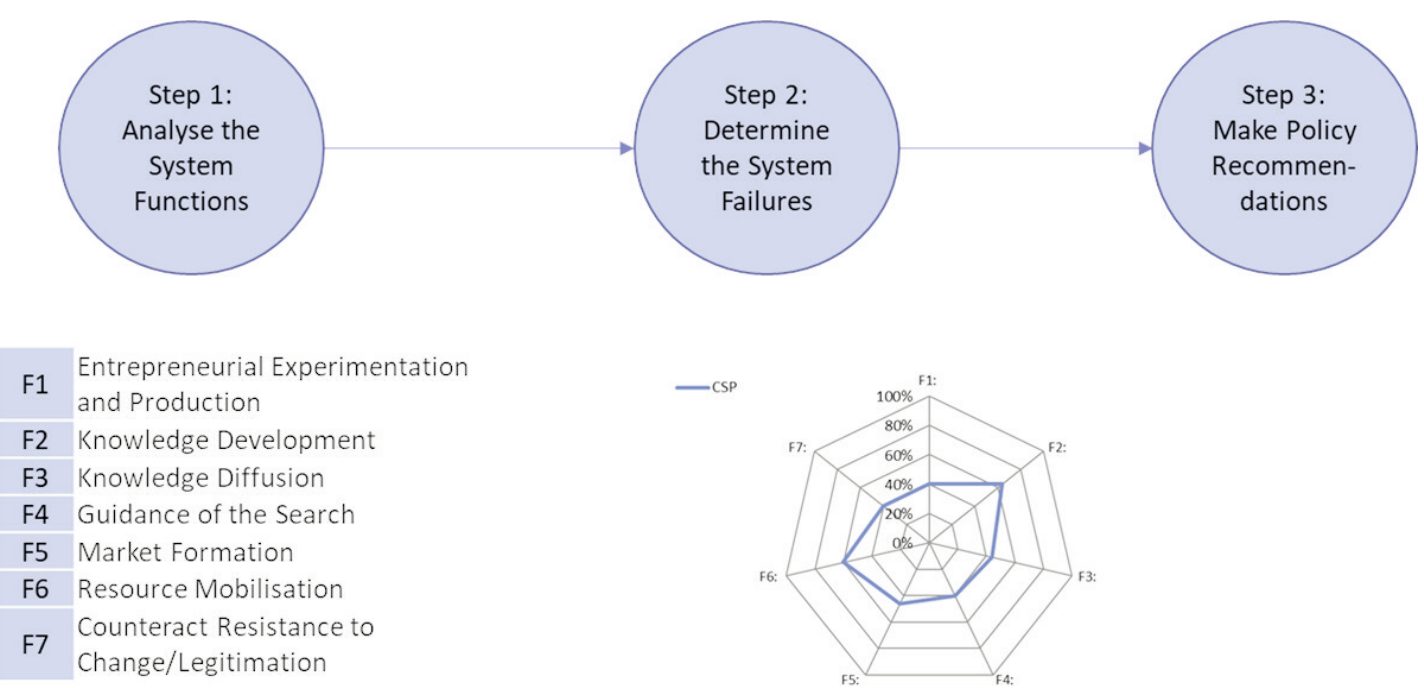

Figure 3. Process for the analysis of a technological innovation system (Hekkert et al., 2011).

2016; Rogge et al., 2016). The latter mix should cover a judicious combination of demand-supply or push-pull instruments, such as market support, through feed-in tariffs with policies to support research and development $(\mathrm{R} \& \mathrm{D})$ or training. The issue of balance between policy mixes is clearly important at all stages of the development of a renewable energy TIS. Moreover, it is not a static mix with a fixed combination of instruments, which is required; different stages need different mixes. For instance, a study of the Chinese wind industry showed that initial growth was high and wellsupported by readily available financial resources, but this growth was subsequently unsustainable because of insufficient attention to the TIS functions of entrepreneurial experimentation (F1) and knowledge development (F2), both of which act on the pull or supply side of the TIS (Karltorp et al., 2017). The issue of sufficient attention to $\mathrm{F} 4$ is common to all the studies. There is a distinction, however, between the results of TIS studies undertaken in developed versus developing countries, to the extent that Edsand (2017) argued for changes to the TIS framework when it is used to analyse developing countries. The proposed modifications include a new sub-function covering the development of adaptive (absorptive) capacity, the separation of resource mobilisation into international and government funding, and the addition of six landscape or exogenous factors including economic growth and climate change. The latter factors are drawn from the literature on multi-level perspective, which identifies shocks in the socio-technical landscape or macro level as being highly important in transition theory (Geels, 2002). It is useful to acknowledge the differences between the TIS results for the developed versus developing country cases despite the changes proposed by Edsand (2017) having not been widely adopted and, as such, not being applied in this study. These studies on developing countries highlight the weakest functions as being F1 (characterised by a weak environment for entrepreneurs and small firms in particular), F2 (very limited local R\&D) and F6 (since developing countries are by definition resource-constrained, weak resource mobilisation is unsurprising) (Walwyn et al., 2018; Kebede and Mitsufuji, 2017; Walwyn, 2016). Addressing these weaknesses is critical to the maturation of RET innovation systems in developing countries. On the other hand, innovation systems in developed countries are generally stronger on the supply side (R\&D and resource mobilisation), but severely constrained by pathway dependence, lock-in and resistance to change, which are all aspects of F7 (Miremadi et al., 2018; Reichardt et al., 2017; Negro et al., 2012). For instance, Negro et al. (2012) found that the weak institutional environment in developed countries tended to block RET development or strengthen the current fossil fuel lock-in. These observations are important to sustainability transitions, since governments need to be proactive in stimulating and steering RET socio-technical systems as part of their broader strategies for sustainability transitions.

\section{Research methodology}

The study was exploratory and adopted a mixed methods approach, using an initial semiquantitative method to establish the extent of maturity of the TIS, followed by an inductive, qualitative approach, using a semi-structured questionnaire, as a means of identifying the key interventions (Sovacool et al., 2018). A nonprobability sampling technique was used, which included both purposive sampling and snowball sampling. Purposive sampling was used to select the initial sample; further respondents were 
then approached based on their recommendations and suggestions (Saunders et al., 2016). Altogether 13 individuals with CSP expertise in a range of areas including research and development, journalism, private sector renewable energy development, development and deployment of renewable energy at Eskom, industrial incentive creation, as well as officials from the REI4P office were interviewed; further information is provided in Table 3 .

Table 3. Description of the interviewees from the sample.

\begin{tabular}{lc}
\hline Description of sector* & $\begin{array}{c}\text { No. of inter- } \\
\text { viewees }\end{array}$ \\
\hline Academia & 3 \\
$\begin{array}{l}\text { Industry experts (consultants and other) } \\
\text { Green financing sector (mainstream }\end{array}$ & 2 \\
and development) & 2 \\
$\begin{array}{l}\text { Public utility (generation) } \\
\text { Private sector (R\&D), product develop- } \\
\text { ment for electricity generation) }\end{array}$ & 2 \\
$\begin{array}{l}\text { Public sector (trade, industry and } \\
\text { innovation promotion) }\end{array}$ & 1 \\
Journalism and publishing & 1 \\
*All respondents connected to concentrated solar power) \\
\hline
\end{tabular}

In qualitative research, the size of the required sample is determined when saturation is reached. Saturation is defined as the point where additional data no longer provides any (or very limited) new insights (Zikmund et al., 2013) and is affected by aspects such as how heterogeneous the population is and how narrow or wide the focus of the research question is. That is, saturation will likely be reached if the sample is taken from a homogenous population and/or the research question is narrow and focused (Saunders et al., 2016). Saturation analysis of the responses, based on the number of new codes created per respondent, showed that no new codes were added for respondents 12 and 13. It was therefore conceded that saturation was reached in the sample. Questions and main themes were sent to the interviewees prior to discussion, to allow them an opportunity to think about their responses so that not too much time was wasted explaining the core concepts. Preference was given to face-to-face interviews, however. Where this was not possible because of diary incompatibility, or the respondent was not located in the same geographic area as the interviewer, telephonic interviews were conducted. All questions and responses were recorded (audio) and transcribed after the interview for data analysis. The researcher also noted on paper any interesting observations, e.g., when a respondent seemed to be hesitant to answer a question during the conversation. In accordance with the exploratory nature of the study, respondents were encouraged to answer questions openly and freely, drawing from their personal experiences throughout the interview process. The text was coded using the Atlas.ti software package thematically, which involved interrogating the text line-by-line and assigning a short phrase to represent the salient features of a key section of text (Zikmund et al., 2013). This code was then assigned to text with similar meaning, but not necessarily the same wording, across the interviews, e.g., varying negative responses received to the question 'Do you think that the policy environment is supportive to entrepreneurs?' were coded as 'supportive environment no'. The code themes, grouped by the categories of TIS function (one), key interventions (two) and future opportunities (three), are shown in Table 4.

\section{Results 4.1 Profile and characterisation of the technological innovation system}

An overview of the respondents' views on the South African CSP TIS is given in Figure 4. Across all the dimensions, it was apparent that the sector is considered to be immature, with the weakest aspects being F1 (entrepreneurial activity), F4 (guidance of the search) and F7 (legitimation), as compared with the results of a similar study undertaken on the South African PV TIS (van Niekerk, 2017). Each function was then discussed in more detail.

F1: The responses corroborated the data of Table 1, which showed that all of the South African CSP projects have used Spanish technology and EPC contractors, with little involvement of local companies and a limited extent of technology transfer from the Spanish companies to the local industry. Some local companies were contracted to provide site utilities and non-proprietary or generic services, as a means of meeting the conditions of the REI4P tender, but the core aspects of each project were provided by the international contractors. The importance of technology transfer and local procurement was recognised in the REI4P and local content formed a significant component of the programme's objectives (Department of Energy, 2018). However, the implementation of these requirements was constrained by a number of factors, including clear loopholes in the regulations, lack of clarity over the rules, inconsistent support for the REI4P, and conflict between different government department on the objectives of the programme (Baker, 2016). 
Table 4. Code themes emerging from analysis of data.

\begin{tabular}{|c|c|c|}
\hline \multirow{3}{*}{$\begin{array}{l}\text { Category } \\
\text { One }\end{array}$} & \multicolumn{2}{|l|}{ Theme } \\
\hline & \multirow{4}{*}{$\begin{array}{l}\text { F1: Entrepreneurial } \\
\text { activity }\end{array}$} & Presence and types of South African firms \\
\hline & & Lost opportunity to develop entrepreneurial activity \\
\hline & & Sentiments related to a supportive entrepreneurial environment \\
\hline & & Challenges and barriers to entrepreneurial activity \\
\hline & \multirow{3}{*}{$\begin{array}{l}\text { F2: Knowledge } \\
\text { development }\end{array}$} & Concentrated solar power research activities in South Africa \\
\hline & & Challenges and barriers to knowledge development \\
\hline & & $\begin{array}{l}\text { Level of knowledge development as it pertains to developing a } \\
\text { competitive concentrated solar power industry in South Africa }\end{array}$ \\
\hline & \multirow{5}{*}{$\begin{array}{l}\text { F3: Knowledge } \\
\text { diffusion }\end{array}$} & Knowledge transfer between academic institutions \\
\hline & & Knowledge transfer between academia and industry \\
\hline & & Knowledge transfer between Eskom and industry \\
\hline & & $\begin{array}{l}\text { Knowledge transfer from international companies to South African } \\
\text { academic institutes and companies }\end{array}$ \\
\hline & & $\begin{array}{l}\text { Level of knowledge diffusion as it pertains to developing a competitive } \\
\text { concentrated solar power industry in South Africa }\end{array}$ \\
\hline & \multirow[t]{4}{*}{$\begin{array}{l}\text { F4: Guidance of } \\
\text { the search }\end{array}$} & $\begin{array}{l}\text { Presence or absence of goals towards the development of concentrated } \\
\text { solar power in South Africa }\end{array}$ \\
\hline & & Presence or absence of supporting policy \\
\hline & & $\begin{array}{l}\text { Current role of the Department of Science and Technology and } \\
\text { Department of Trade and Industry }\end{array}$ \\
\hline & & $\begin{array}{l}\text { Future role of the Department of Science and Technology and } \\
\text { Department of Trade and Industry }\end{array}$ \\
\hline & \multirow[t]{2}{*}{$\begin{array}{l}\text { F5: Market } \\
\text { formation }\end{array}$} & $\begin{array}{l}\text { Description and definition of the concentrated solar power market in } \\
\text { South Africa }\end{array}$ \\
\hline & & Role and impact of the REI4P* on market formation \\
\hline & \multirow[t]{3}{*}{$\begin{array}{l}\text { F6: Resource } \\
\text { mobilisation }\end{array}$} & $\begin{array}{l}\text { Role of the REI4P* in creating sufficient financial incentive to develop } \\
\text { the South African concentrated solar power market }\end{array}$ \\
\hline & & Funding availability \\
\hline & & Skilled human resources \\
\hline & \multirow{4}{*}{$\begin{array}{l}\text { F7: Counteract } \\
\text { resistance to } \\
\text { change/legitimacy } \\
\text { creation }\end{array}$} & Advocacy groups and their actions \\
\hline & & Counter lobby actions \\
\hline & & Negative perception that has been created about CSP \\
\hline & & Barrier formation through bureaucracy \\
\hline \multirow[t]{6}{*}{ Two } & & Solutions to improving entrepreneurial experimentation \\
\hline & & Solutions to increasing knowledge development \\
\hline & & Solutions to improving knowledge diffusion \\
\hline & & Solutions to improving guidance of the search \\
\hline & & Solutions to increase resource mobilisation \\
\hline & & Solutions to improving legitimacy creation \\
\hline \multirow[t]{3}{*}{ Three } & & $\begin{array}{l}\text { General disadvantages of concentrated solar power over other renewable } \\
\text { energy technologies }\end{array}$ \\
\hline & & Challenges for concentrated solar power in the South African context \\
\hline & & Potential for concentrated solar power in the South African context \\
\hline
\end{tabular}

As a result, the potential impact of the programme on the local manufacturing sector was transient and weak. In the case of CSP, the main reason for the limited development of local entrepreneurs was issues related to capital risk. The CSP plants are highly capital-intensive, the cost of a commercial 100 MW CSP plant being close to USD 1 billion (IRENA Secretariat, 2012). As a result, financiers are averse to supporting projects that may involve untested technology or inexperienced entrepreneurs. The CSP remains an expensive technology to develop and commercialise, an aspect which prevents the entry of new competitors. 


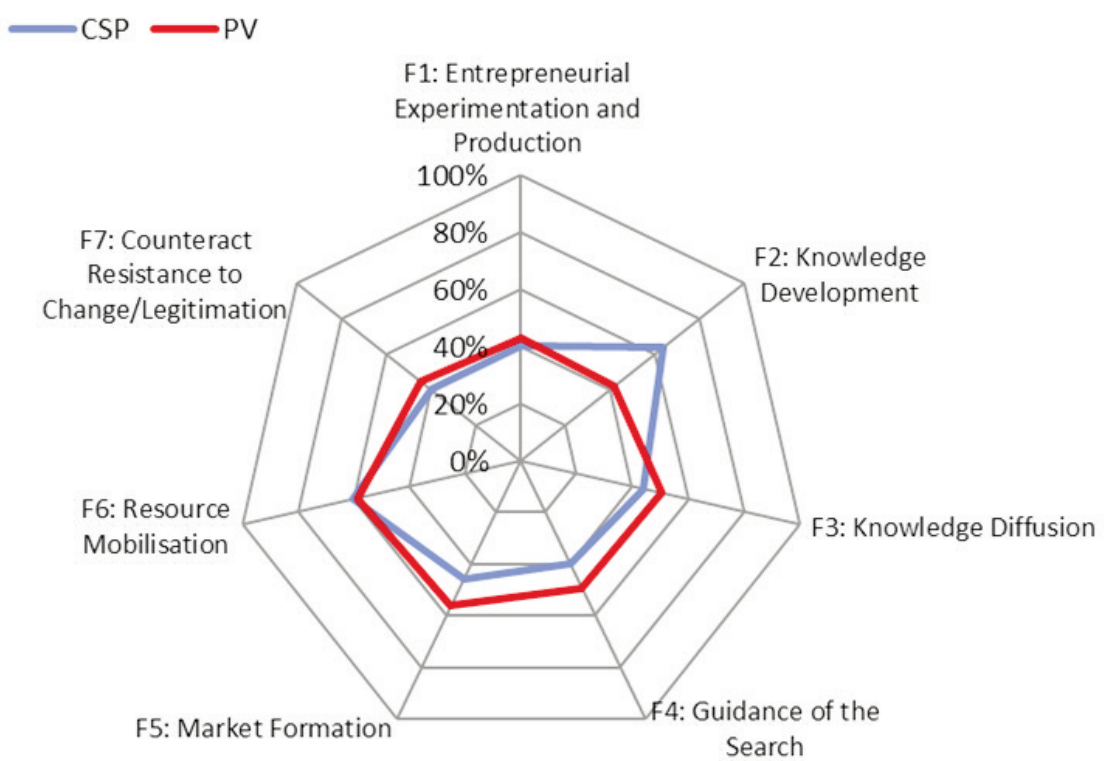

\section{Figure 4. Respondents' perceptions of the concentrated solar power technological innovation system (compared to photovoltaics).}

Moreover, only companies that are certified by the International Electrotechnical Commission are permitted to participate in the REI4P (Baker, 2016). This requirement particularly affects the potential benefits to entrepreneurs who are not able to obtain such certification. Concerns about the future of the REI4P, initially as a result of the strong nuclear lobby and, more recently, arising from the weak financial position of Eskom (which procures the power from the independent power producers), was also considered to be a limiting factor for the development of CSP entrepreneurs. Consistent demand-side support is essential for creating sufficient risk mitigation factors for entrepreneurs. In the absence of such consistency, entrepreneurs cannot access either financial resources or local revenue streams and will not survive. Conditions for supporting F1 must include a policy mix that combines demandand supply-side incentives on a consistent basis

F2: There are several local university-based research groups focussed on CSP, including Solar Thermal Energy Research Group at the University of Stellenbosch, Western Cape (-33.9328078,18.8622583), the Group for Solar Thermal Dynamics at the University of KwaZulu-Natal, KwaZulu-Natal (-29.8674219, 30.9785385) and the Clean Energy Research Group at the University of Pretoria, Gauteng $(-25.7545492,28.2292589)$. The groups are important in the overall development of the innovation system, since they train graduates who may find employment on the CSP plants or become entrepreneurs, working in their own start-ups; they develop local technologies; they actively source and evaluate new technologies; and they improve the overall technological absorptive capability of the industry. It is apparent that there is activity in this area and the function was ranked as one of the most developed in the CSP TIS because of the legacy of established institutes. Nevertheless, the absolute value is still below $60 \%$, reflecting the dynamic landscape for CSP research and the importance of a technological breakthrough that would place CSP in a more competitive position with respect to the other emerging renewable energy technologies.

F3: Knowledge diffusion between academic institutions, particularly between local and abroad, was reported to be significant, and the respondents reported a high degree of interaction on CSP. Such strength was, however, not evident between firms, or between large firms and academia. This weakness reflects the embryonic nature of the system, which is still characterised by centres of academic excellence disconnected from large firms, most of the latter being international organisations with a weak presence in South Africa. The transition of a technological innovation system from this embryonic state to a functional system that is less dependent on international technology transfer and able to compete internationally, based on domestic innovation implemented by commercial firms with strong market presence, is an imperative which has so far evaded the South African renewable energy sector. Despite a number of policy initiatives to diversify the country's economy from its reliance on resource extraction to a spectrum of value-adding activ- 
ities based on high levels of technological innovation, such changes have been minimal (OECD, 2017). The CSP as a manufacturing activity is no exception to this overall resistance to technological transition, the reasons for which are discussed in more detail in Section 5.

F4: The general view from the study was that the system was not well directed and had no clear goals or policies. Furthermore the exclusion of CSP from the most recent bidding windows of the REI4P was seen as an indication of government's loss of interest in CSP, despite the opportunity that the technology still offered to the local power and manufacturing sectors (Craig et al., 2017). It was also stated that CSP would benefit from more evident policy alignment. There was a general sense that different sections government seem intent on pursuing policy in support of their own departmental plans and interests, without due concern for the synergies that may come from co-operation. A clear example of the lack of alignment was the tension between the objectives of the Department of Energy and National Treasury to mitigate emissions at the lowest possible cost, versus the goals of the Department of Trade and Industry to establish local industry, versus those of the Department of Science and Technology to foster scientific research in the country. Aside from two respondents, all interviewees felt that the Department of Trade and Industry and the Department of Science and Technology should be more active within their respective mandates in developing CSP, even if this were to lead to higher costs for procurement in the short term.

F5: Market demand for CSP will, in one way or another, ultimately determine the future of CSP. At present, the demand is limited by its technoeconomic disadvantages (see Section 4.2 for a detailed discussion of CSP costs) and the further expansion of CSP is being driven by market subsidies and incentives, provided on the basis that it is an immature technology that requires such interventions if it is ever to become widely adopted. The respondents generally agreed that CSP is not competitive, a perspective supported by the data in Section 4.2, and that it would not have gained presence in the market were it not for the REI4P, which included a provision dedicated to CSP. Demand-side measures, which create artificial markets through mechanisms of protection, may be essential in the commercialisation of an embryonic technology, but can also create a longer-term dependence or expectation of government support. The problem of dependence was already evident in the replies to the questionnaire, the respondents acknowledging that without the REI4P there would be no CSP industry at all, but complaining that the allocations were too small and the tariffs too low (inadequately recognising the value of CSP in being able to deliver peak power). This issue of cost competitiveness is discussed in more detail in Section 4.2.

F6: The availability of resources was generally not considered to be a major barrier to the further development of the CSP TIS. As shown in Table 1, USD 4.6 billion has already been secured and invested in the sector, with a further USD 715 million being planned (the Redstone facility). Furthermore, the respondents were of the view that additional finance and human resources could be found, should the industry be able to expand. Despite South Africa not being a technology leader, it was considered that there is significant local capability and that further capabilities could be developed, should the market expand.

F7: The interviewees were asked about the perceived public opinion of CSP and support from the media to establish the strength of advocacy and lobby groups for CSP. Many respondents felt that technology was poorly understood by the public and that its potential impact was not adequately covered by the media, including aspects such as its socio-economic benefit to marginal areas and the ability to deliver peak power. There were also reports of conflict and confusion between the two active lobby groups, criticism of their delivery and questions as to whether both groups were required. It was felt that a single body with active campaigns could be more effective in securing public support for CSP.

In summary, the CSP TIS in South Africa has strengths in the area of knowledge development and resource mobilisation, but it is mostly a weak system with limited entrepreneurial activity, a heavy dependence on international technology, limited policy support and inadequate efforts to address legitimation and resistance. Given that it is still a costly alternative to other RETs, measures to strengthen these factors are essential. In the next section, the cost issue is examined in more detail as a step towards defining the necessary policy interventions.

\subsection{Cost of concentrated solar power}

The levelised cost of electricity (LCOE) for the various RETs in years 2010 and 2018 is given in Figure 5. It can be seen that in most cases the 


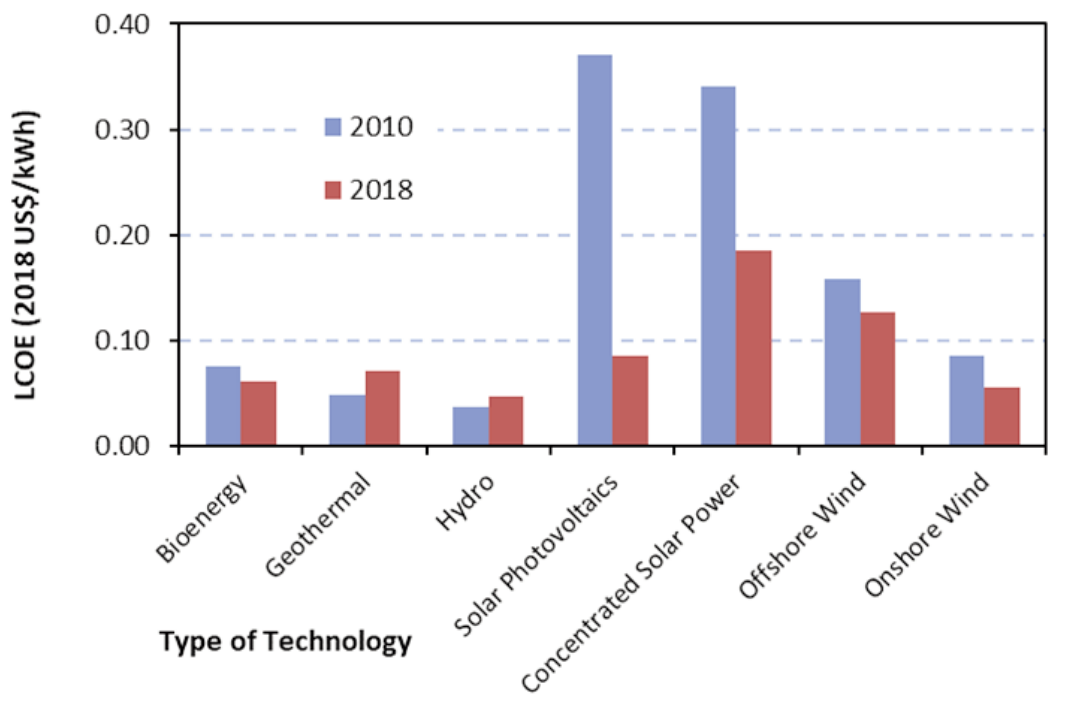

Figure 5. Global levelised cost of electricity of utility-scale renewable energy technologies, 2010 and 2018 (IRENA, 2019).

LCOE has significantly decreased, reaching cost parity with fossil fuel-based energy generation, the latter being between USD $0.6 / \mathrm{kWh}$ and USD 1.43/kWh (Lazard, 2018; Walwyn and Brent, 2014). The exception is CSP, which is still somewhat above the upper bound of the fossil fuel band, with the solar tower being the least expensive of the three dominant options (Salisu et al., 2019).

In a more recent techno-economic study, comparing the relative costs of solar towers and parabolic troughs, Pan et al. (2019) reported that solar towers could breach the USD $0.10 / \mathrm{kWh}$ barrier, and were generally more cost-effective than parabolic troughs. Furthermore, there have been several recent reports of cost-competitive CSP facilities, with costs as low as USD $0.07 / \mathrm{kWh}$ having been bid for projects in Australia and Dubai (Pan et al., 2019; Lilliestam and Pitz-Paal, 2018; Kraemer, 2017), indicating that with low land, finance and construction costs, energy costs approaching those of wind and solar PV are still possible. A breakdown of the capital costs involved in construction of a tower CSP plant is given in Figure 6, where the heliostats account for 38\% of the total cost of the plant (Black and Veatch, 2012). This area is therefore subject of much R\&D aimed at increasing efficiencies and reducing cost. Additional cost reductions could come from installing larger plants (economies of scale are reached above $130 \mathrm{MW}$ installed capacity) and standardisation of components. The high cost can be mitigated, at least in part, by capturing the true value of peak electricity dispatch (Dowling et al., 2017). The latter is an important issue; the LCOE comparison of CSP versus PV, for instance, does not capture the value of peak electricity and as a consequence does not reflect the true market value of CSP (Joskow, 2011). It

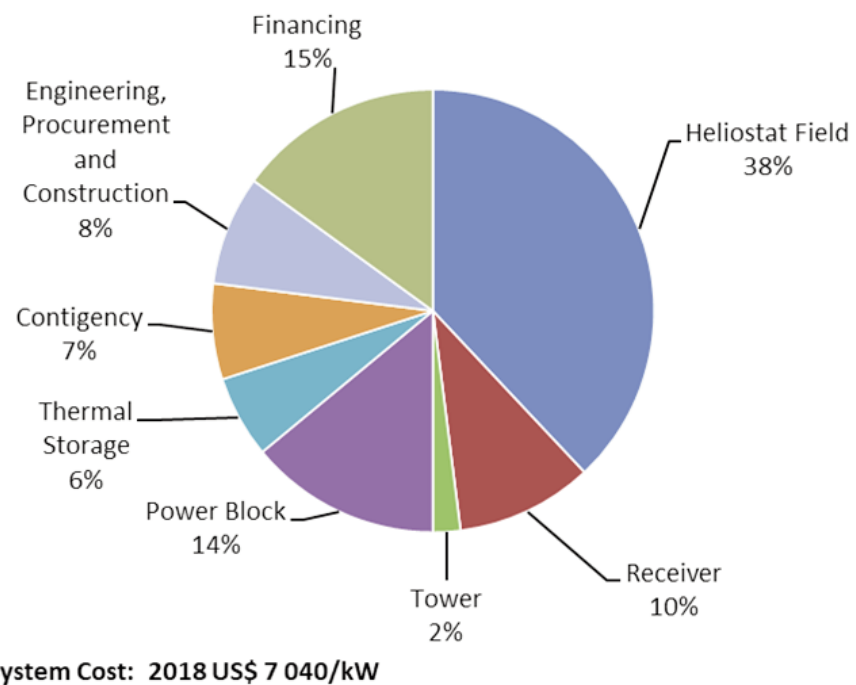

Total System Cost: 2018 US\$ $7040 / k W$

Figure 6. Capital cost breakdown for a tower concentrated solar power plant with thermal storage (Black and Veatch, 2012). 


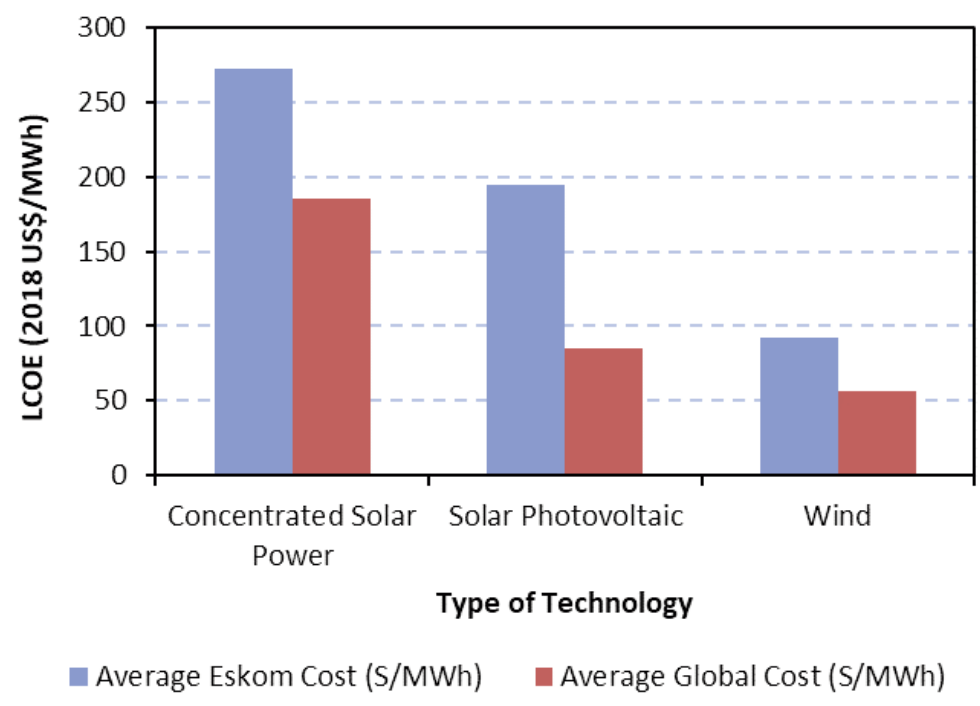

Figure 7. Cost comparison of renewable energy in South Africa, 2019 (Eskom, 2019).

would be more appropriate to compare CSP with PV plus storage than with PV on its own, as was adopted in the case of the Australian and South African plants. If these business models can be replicated in other regions, it may signal the commercial breakthrough that CSP requires to compete in the renewable energy market.

Nevertheless, the relatively high cost of electricity from CSP plants remains a significant barrier to the wider acceptance of CSP. For instance, the cost of CSP energy to Eskom, the South African parastatal responsible for generation, distribution and supply, was USD 272/MWh in the 2018/19 financial year (Figure 7). Indeed, the premium for CSP energy has been considered as excessive and has precipitated calls for a three-year suspension of the REI4P and retroactive tariff cuts (Steyn, 2019). Such perceptions negatively impact on public opinion and the adoption of RET and need to be properly managed if the sector is to move forward.

\section{Discussion}

The objective of this research was to establish whether the CSP sector in South Africa could become a globally competitive, export-oriented industry. The TIS framework was used as a means of establishing whether the system had matured sufficiently for it to enter such markets, or whether it remained significantly underdeveloped. The results have shown that it is still a niche technology and requires on-going public policy interventions to ensure the processes of deepening, broadening and scaling up are completed successfully (Van den Bosch et al., 2008). There are two separate discussions that emerge from the study and the future of CSP in South Africa: the extent to which CSP can be a viable or significant source of electricity in the country, and whether South Africa can become a globally competitive manufacturing base for CSP equipment. The first issue is important for the country's energy infrastructure and the potential of CSP to contribute to the decarbonisation of the economy, the second is relevant to the quest of economic growth and the creation for employment. Both issues are impacted heavily by the common concern of economic feasibility. Despite the acknowledged limitations of techno-economic assessments, given that the results rely on the quality of the input assumptions and can be used as a means to resist change rather than support evidence-based decisions, it is clear that the average costs of CSP are higher than other forms of renewable energy, including the costs of energy storage to achieve an equivalent level of dispatchability (Section 4.2). In short, PV or wind in combination with gas turbine generation are both more attractive than CSP under present conditions. Moreover, the declining costs of storage may further undermine the competitiveness of CSP. This perspective on the rather limited prospects for CSP is not universally shared in the literature, as there are claims that CSP is already competitive, if the value of delivering non-carbon emitting power outside of normal daylight hours is acknowledged and appropriately rewarded (Lilliestam and Pitz-Paal, 2018; Ling-zhi et al., 2018). The contradictory reports arise from the lack of a standardised approach to the important question of the time-varying value of electricity and the fact that the conventional approach, based on LCOE, significantly underestimates the value of energy storage (Dowling et al., 2017). The development of such standardised approaches that will allow the true values to be more directly compared remains a neglected aspect in the energy field. Given the 
uncertainty of the present valuations, it is apparent that further development should continue and should seek innovative approaches to reduce CSP's LCOE cost. In South Africa, the results of this study suggest that a procurementdriven industrial strategy, well aligned with science, technology and innovation policies, will be an important factor in achieving the objective of developing the sector. In-country demand needs to be created, e.g., through a demand-side programme like the REI4P, to attain a critical mass of technology to develop tacit knowledge around the design, manufacture, operation and maintenance of the plants. This market demand must be supported by strong industrialisation policies aimed at building localised services and manufacturing, and requires the alignment of energy policy (to increase CSP procurement objectives, lower risk and incentivise investment), climate policy (incentivise RET uptake through mechanisms such as emissions taxes) and industrial policy (to incentivise manufacturing and knowledge development). It was suggested that one method of accelerating knowledge development and encouraging participation from both the private and public sector will be to develop a centralised solar thermal knowledge centre in South Africa using public and private funding, similar to the Plataforma Solar de Alemeria in Spain. This kind of research centre is aimed at developing and testing solar technology (F2) and fostering collaboration (F3) between academia, industry and international experts on the matter. It also provides a platform for piloting technology to allow a prospective technology to accumulate sufficient hours on-line to demonstrate its commercial readiness (F2), and over time to lower the risk profile of a new technology, which encourages investment from potential investors (F6). The investment then increases the number of entrepreneurs (F1) able to enter the market (F5). Piloting also provides an opportunity to influence the design process to support manufacturing capabilities and regular training seminars also ensure a pipeline of skilled human resources (F6) to address any areas with critical resource shortage.

\section{Conclusions}

This study has sought to understand the reasons for the inability of the South African concentrated solar power (CSP) sector to develop into a fully functional and mature technological innovation system. An exploratory, mixed methods approach was followed to assess the seven factors of the technological innovation systems (TIS), and then develop a set of recommendations for future policy action. It is evident from the results that the CSP TIS is weak in the areas of entrepreneurial experimentation (F1), guidance of the search (F4) and legitimacy creation (F7). In this respect, it shares a weakness in legitimacy creation (F7) and a strength in resource mobilisation (F6) and knowledge development (F2) with developed countries, and shares a weakness in entrepreneurial activity with developing countries. Further growth of the sector will depend on policies to reduce its reliance on imported technologies and local demand side support.

The emergence of CSP as a globally significant renewable energy technology (RET) will depend on its ability to compete with solar photovolataics on a techno-economic basis. At this stage, CSP accounts for a small fraction (about $1.3 \%$ in 2017) of global investment in solarbased RET. Expanding and scaling-up the technology will require further improvements in its key performance parameters, particularly lower capital and operating costs. Recent studies have suggested that CSP could be cost competitive, but such claims have not yet been demonstrated on large-scale installations. Should these advances be made, South Africa will need to strengthen its supply-side policy support for CSP entrepreneurs, in addition to the direct use of local procurement processes, if it is to position the local CSP industry as a global player.

\section{Author roles}

S. Potts undertook the research for this project under Professor Walwyn's supervision

D.R. Walwyn provided the initial input for the project, supervised the work and prepared the final article for submission based on the initial mini-dissertation and updated information.

\section{References}

Andersson, J., Hellsmark, H. \& Sandén, B. A. 2018. Shaping factors in the emergence of technological innovations: The case of tidal kite technology. Technological Forecasting and Social Change, 132(7), 191-208. doi: 10.1016/j.techfore.2018.01.034

Baker, D. L. 2016. Technology development in South Africa: The case of wind and solar PV. Science Policy Research Unit: Sussex.

Behar, O., Khellaf, A. \& Mohammedi, K. 2013. A review of studies on central receiver solar thermal power plants. Renewable and Sustainable Energy Reviews, 23(7), 12-39.

Bento, N. \& Fontes, M. 2015. The construction of a new technological innovation system in a follower 
country: Wind energy in Portugal. Technological Forecasting and Social Change, 99, 197-210. doi: http://dx.doi.org/10.1016/j.techfore.2015.06.037

Bergek, A., Hekkert, M., Jacobsson, S., Markard, J., Sandén, B. \& Truffer, B. 2015. Technological innovation systems in contexts: Conceptualizing contextual structures and interaction dynamics. Environmental Innovation and Societal Transitions, 16, 51-64. doi: 10.1016/j.eist.2015.07.003

Bergek, A., Jacobsson, S., Carlsson, B., Lindmark, S. \& Rickne, A. 2008a. Analyzing the functional dynamics of technological innovation systems: A scheme of analysis. Research Policy, 37(3), 407-429.

Bergek, A., Jacobsson, S. \& Sandén, B. A. 2008b. 'Legitimation' and 'development of positive externalities': Two key processes in the formation phase of technological innovation systems. Technology Analysis \& Strategic Management, 20(5), 575-592. doi: 10.1080/09537320802292768

Bischof-Niemz, T. 2019. Powerfuels and its potential for South Africa. Berlin Energy Transition Dialogue 2019, Berlin [Online]. Available: https://energytransitionsa.files.wordpress.com/2019/04/betd-powerfuels-enertrag-tbn_8apr2019_sent-1.pdf [Accessed 9 September 2019].

Black and Veatch. 2012. Cost and performance data for power generation technologies. Black and Veatch: Kansas.

Carlsson, B. \& Stankiewicz, R. 1991. On the nature, function and composition of technological systems. Journal of Evolutionary Economics, 1(2), 93-118.

Chung, S. 2002. Building a national innovation system through regional innovation systems. Technovation, 22(8), 485-491.

Craig, O. O., Brent, A. C. \& Dinter, F. 2017. Concentrated solar power (CSP) innovation analysis in South Africa. South African Journal of Industrial Engineering, 28(2), 14-27. doi: 10.7166/28-2-1640

Department of Energy. 2018. Independent Power Producers Procurement Programme (IPPPP): An overview (March 2018). Department of Energy: Pretoria.

Dewald, U. \& Truffer, B. 2011. Market formation in technological innovation systems: Diffusion of photovoltaic applications in Germany. Industry \& Innovation, 18(3), 285-300. doi: 10.1080/13662716.2011.561028

Dowling, A. W., Zheng, T. \& Zavala, V. M. 2017. Economic assessment of concentrated solar power technologies: A review. Renewable and Sustainable Energy Reviews, 72(5), 1019-1032. doi: https://doi.org/10.1016/j.rser.2017.01.006

Edsand, H.-E. 2017. Identifying barriers to wind energy diffusion in Colombia: A function analysis of the technological innovation system and the wider context. Technology in Society, 49, 1-15.

Energyblog. 2019. Project Database [Online]. Johannesburg: Energyblog. Available: https://www.energy.org.za/data-and-tools/project-database [Accessed 9 September].

Eskom. 2019. Integrated report. Eskom: Johannesburg. Available: http://www.eskom.co.za/IR2019/Documents/Eskom_2019_integrated_report.pdf. [Accessed 13 September 2019].

Fuqiang, W., Ziming, C., Jianyu, T., Yuan, Y., Yong, S. \& Linhua, L. 2017. Progress in concentrated solar power technology with parabolic trough collector system: A comprehensive review. Renewable and Sustainable Energy Reviews, 79(11), 1314-1328. doi: https://doi.org/10.1016/j.rser.2017.05.174

Geels, F. \& Raven, R. 2006. Non-linearity and expectations in niche-development trajectories: Ups and downs in Dutch biogas development (1973-2003). Technology Analysis \& Strategic Management, 18(3-4), 375-392.

Geels, F. W. 2002. Technological transitions as evolutionary reconfiguration processes: A multi-level perspective and a case-study. Research Policy, 31(8-9), 1257-1274.

Godin, B. 2009. National Innovation System. Science, Technology, \& Human Values, 34(4), 476-501. doi: doi:10.1177/0162243908329187

Hekkert, M., Negro, S., Heimeriks, G. \& Harmsen, R. 2011. Technological Innovation System Analysis. A manual for analysts, Universiteit Utrecht.

Hekkert, M. P., Suurs, R. A. A., Negro, S. O., Kuhlmann, S. \& Smits, R. E. H. M. 2007. Functions of innovation systems: A new approach for analysing technological change. Technological Forecasting and Social Change, 74(4), 413-432. doi: 10.1016/j.techfore.2006.03.002

IRENA [International Renewable Energy Agency]. 2018. Renewable capacity statistics 2018. The International Renewable Energy Agency: Abu Dhabi. Available: www.irena.org/Publications.

IRENA [International Renewable Energy Agency]. 2019. Renewable power generation costs in 2018. International Renewable Energy Agency (IRENA): Abu Dhabi. Available: www.irena.org/home/publications.

IRENA [International Renewable Energy Agency] Secretariat. 2012. Renewable energy technologies: Cost analysis series - solar photovoltaics. IRENA Working Paper, IRENA: Bonn. 
Islam, M. T., Huda, N., Abdullah, A. \& Saidur, R. 2018. A comprehensive review of state-of-the-art concentrating solar power (CSP) technologies: current status and research trends. Renewable and Sustainable Energy Reviews, 91(8), 987-1018.

Jacobsson, S. 2008. The emergence and troubled growth of a 'biopower' innovation system in Sweden. Energy Policy, 36(4), 1491-1508. doi: 10.1016/j.enpol.2007.12.013

Jacobsson, S. \& Johnson, A. 2000. The diffusion of renewable energy technology: An analytical framework and key issues for research. Energy Policy, 28(9), 625-640.

Jacobsson, S. \& Karltorp, K. 2013. Mechanisms blocking the dynamics of the European offshore wind energy innovation system: Challenges for policy intervention. Energy Policy, 63, 1182-1195. doi: 10.1016/j.enpol.2013.08.077

Joskow, P. L. 2011. Comparing the costs of intermittent and dispatchable electricity generating technologies. American Economic Review, 101(3), 238-41.

Kaihua, C. \& Mingting, K. 2014. Staged efficiency and its determinants of regional innovation systems: A two-step analytical procedure. Annals of Regional Science, 52(2), 627-657.

Karltorp, K., Guo, S. \& Sandén, B. A. 2017. Handling financial resource mobilisation in technological innovation systems: The case of Chinese wind power. Journal of Cleaner Production, 142, 3872-3882. doi: 10.1016/j.jclepro.2016.10.075

Kebede, K. Y. \& Mitsufuji, T. 2017. Technological innovation system building for diffusion of renewable energy technology: A case of solar PV systems in Ethiopia. Technological Forecasting and Social Change, 114, 242-253. doi: 10.1016/j.techfore.2016.08.018

Kemp, R., Schot, J. \& Hoogma, R. 1998. Regime shifts to sustainability through processes of niche formation: the approach of strategic niche management. Technology analysis \& strategic management, 10(2), 175-198.

Kraemer, S. 2017. Solar thermal power prices have dropped an astonishing 50\% in six months [Online]. Tabernas: SolarPACES. Available: https://www.solarpaces.org/solar-thermal-energy-prices-drophalf/ [Accessed 13 September].

Lazard. 2018. Levelized cost of energy and levelized cost of storage 2018 [Online]. New York: Lazard. Available: https://www.lazard.com/perspective/levelized-cost-of-energy-and-levelized-cost-of-storage-2018/ [Accessed 5 August].

Lilliestam, J. \& Pitz-Paal, R. 2018. Concentrating solar power for less than USD 0.07 per kWh: Finally the breakthrough? Renewable Energy Focus, 26, 17-21. doi:

https://doi.org/https://doi.org/10.1016/j.ref.2018.06.002

Ling-zhi, R., Xin-gang, Z., Yu-zhuo, Z. \& Yan-bin, L. 2018. The economic performance of concentrated solar power industry in China. Journal of Cleaner Production, 205(12), 799-813. doi: https://doi.org/10.1016/j.jclepro.2018.09.110

Lundvall, B.-A. 2010. National systems of innovation: Toward a theory of innovation and interactive learning, London: Anthem Press.

Lundvall, B.-Å., Johnson, B., Andersen, E. S. \& Dalum, B. 2002. National systems of production, innovation and competence building. Research Policy, 31(2), 213-231.

Macknick, J., Newmark, R., Heath, G. \& Hallett, K. C. 2012. Operational water consumption and withdrawal factors for electricity generating technologies: A review of existing literature. Environmental Research Letters, 7(4), 045802.

Mahlangu, N. \& Thopil, G. A. 2018. Life cycle analysis of external costs of a parabolic trough concentrated solar power plant. Journal of Cleaner Production, 195(9), 32-43.

Malerba, F. 2002. Sectoral systems of innovation and production. Research Policy, 31(2), $247-264$.

Markard, J. \& Truffer, B. 2008a. Actor-oriented analysis of innovation systems: exploring micro-meso level linkages in the case of stationary fuel cells. Technology Analysis \& Strategic Management, 20(4), 443-464. doi: 10.1080/09537320802141429

Markard, J. \& Truffer, B. 2008b. Technological innovation systems and the multi-level perspective: Towards an integrated framework. Research Policy, 37(4), 596-615. doi: 10.1016/j.respol.2008.01.004

Miremadi, I., Saboohi, Y. \& Jacobsson, S. 2018. Assessing the performance of energy innovation systems: Towards an established set of indicators. Energy Research \& Social Science, 40, 159-176. doi: 10.1016/j.erss.2018.01.002

Musiolik, J. \& Markard, J. 2011. Creating and shaping innovation systems: Formal networks in the innovation system for stationary fuel cells in Germany. Energy Policy, 39(4), 1909-1922. doi: 10.1016/j.enpol.2010.12.052

Negro, S. O., Alkemade, F. \& Hekkert, M. P. 2012. Why does renewable energy diffuse so slowly? A review of innovation system problems. Renewable and Sustainable Energy Reviews, 16(6), 3836-3846. doi: 10.1016/j.rser.2012.03.043 
Nelson, J., Gambhir, A. \& Ekins-Daukes, N. 2014. Solar power for $\mathrm{CO}^{2}$ mitigation. Grantham Institute for Climate Change, Imperial College: London.

Nelson, V., Rueda, X. \& Vermeulen, W. J. V. 2018. Challenges and opportunities for the sustainability transition in global trade (Introduction). Business Strategy and the Environment, 27(2), 173-178. doi: 10.1002/bse.2008

OECD [Organisation for Economic Co-operation and Development]. 2017. OECD economic surveys: South Africa. OECD: Paris.

Pan, C. A., Guédez, R., Dinter, F. \& Harms, T. M. 2019. A techno-economic comparative analysis of thermal oil and molten salt parabolic trough power plants with molten salt solar towers. AIP Conference Proceedings, 2126(1), 120014. doi: 10.1063/1.5117632

Planko, J., Cramer, J., Hekkert, M. P. \& Chappin, M. M. H. 2017. Combining the technological innovation systems framework with the entrepreneurs' perspective on innovation. Technology Analysis \& Strategic Management, 29(6), 614-625. doi: 10.1080/09537325.2016.1220515

Reddy, V. S., Kaushik, S., Ranjan, K. \& Tyagi, S. 2013. State-of-the-art of solar thermal power plants: A review. Renewable and Sustainable Energy Reviews, 27(11), 258-273.

Reichardt, K., Negro, S. O., Rogge, K. S. \& Hekkert, M. P. 2016. Analyzing interdependencies between policy mixes and technological innovation systems: The case of offshore wind in Germany. Technological Forecasting and Social Change, 106, 11-21. doi: 10.1016/j.techfore.2016.01.029

Reichardt, K., Rogge, K. S. \& Negro, S. O. 2017. Unpacking policy processes for addressing systemic problems in technological innovation systems: The case of offshore wind in Germany. Renewable and Sustainable Energy Reviews, 80, 1217-1226. doi: 10.1016/j.rser.2017.05.280

Relancio, J., Cuellar, A., Walker, G. \& Ettmayr, C. South African CSP projects under the REIPPP programme - Requirements, challenges and opportunities. SOLARPACES 2015: International Conference on Concentrating Solar Power and Chemical Energy Systems, Cape Town. AIP Conference Proceedings, 1734(1), 2-12.

REN21. 2019. Renewables 2019: Global status report. REN21 Secretariat: Paris.

Rogge, K. S. \& Reichardt, K. 2016. Policy mixes for sustainability transitions: An extended concept and framework for analysis. Research Policy, 45(8), 1620-1635. doi: 10.1016/j.respol.2016.04.004

Salisu, L., Enaburekhan, J. \& Adamu, A. 2019. Techno-economic and life cycle analysis of energy generation using concentrated solar Power (CSP) technology in Sokoto State. Nigeria. Journal of Applied Sciences and Environmental Management, 23(5), 775-782.

Saunders, M., Lewis, P. \& Thornhill, A. 2016. Research methods for business students, 7th edition, Harlow: Pearson Education Limited.

SolarPACES. 2019. CSP projects around the world [Online]. Tabernas, Spain: SolarPACES (Solar power and chemical energy systems). Available: https://www.solarpaces.org/csp-technologies/csp-projectsaround-the-world/ [Accessed 19 May 2020].

Soomro, M. I., Mengal, A., Memon, Y. A., Khan, M. W. A., Shafiq, Q. N. \& Mirjat, N. H. 2019. Performance and economic analysis of concentrated solar power generation for Pakistan. Processes, 7(9), 575-600. doi: 10.3390/pr7090575

Sovacool, B. K., Axsen, J. \& Sorrell, S. 2018. Promoting novelty, rigor, and style in energy social science: towards codes of practice for appropriate methods and research design. Energy Research \& Social Science, 45, 12-42.

Steyn, L. 2019. Light in the dark. Financial Mail, Available: https://www.pressreader.com/southafrica/financial-mail/20190829/281835760366842.

Suurs, R. A. A. \& Hekkert, M. P. 2009. Cumulative causation in the formation of a technological innovation system: The case of biofuels in the Netherlands. Technological Forecasting and Social Change, 76(8), 1003-1020. doi: 10.1016/j.techfore.2009.03.002

Teske, S., Leung, J., Crespo, L., Bial, M., Dufour, E., Richter, C. \& Rochon, E. 2016. Solar thermal electricity: Global outlook 2016. European Solar Thermal Electricity Association, Greenpeace International: Amsterdam.

Trieb, F., Schillings, C., O'Sullivan, M., Pregger, T. \& Hoyer-Klick, C. 2009. Global potential of concentrating solar power. SolarPaces Conference Berlin, Berlin [Online]. Available: https://www.dlr.de/tt/Portaldata/41/Resources/dokumente/institut/system/projects/reaccess/DNIAtlas-SP-Berlin_20090915-04-Final-Colour.pdf [Accessed 1 August 2019].

Van den Bosch, S. \& Rotmans, J. 2008. Deepening, broadening and scaling up: A framework for steering transition experiments. Knowledge Centre for Sustainable System Innovations and Transitions: Delft.

Van Niekerk, D. G. L. 2017. An assessment of the South African photovoltaic sector within the technological innovation system framework. MSc (Engineering) thesis, University of Pretoria (Pretoria). 
Available from http://hdl.handle.net/2263/64850 (last accessed on 7 October 2019)

Walwyn, D., Bertoldi, A. \& Gable, C. 2018. Building the hydrogen economy through niche experimentation and digitalisation. Journal of Manufacturing Technology Management. doi: 10.1108/JMTM-112017-0247

Walwyn, D. R. 2016. The use of the technological innovation systems framework to identify the critical factors for a successful sustainability transition to rooftop solar in low-income communities within South Africa. In: Zobaa, A. F., Afifi, S. N. \& Pisica, I. (Eds.) Sustainable energy: Technological issues, applications and case studies. Rijeka: InTech, Ch, Ch. 03.

Walwyn, D. R. \& Brent, A. C. 2014. Renewable energy gathers steam in South Africa. Renewable and Sustainable Energy Reviews, 41(2015), 390-401.

Wieczorek, A. J., Negro, S. O., Harmsen, R., Heimeriks, G. J., Luo, L. \& Hekkert, M. P. 2013. A review of the European offshore wind innovation system. Renewable and Sustainable Energy Reviews, 26(10), 294-306. doi: 10.1016/j.rser.2013.05.045

Wirth, S. \& Markard, J. 2011. Context matters: How existing sectors and competing technologies affect the prospects of the Swiss Bio-SNG innovation system. Technological Forecasting and Social Change, 78(4), 635-649. doi: 10.1016/j.techfore.2011.01.001

Zhang, H., Baeyens, J., Degrève, J. \& Cacères, G. 2013. Concentrated solar power plants: Review and design methodology. Renewable and Sustainable Energy Reviews, 22(6), 466-481. 